\title{
The Effectiveness of Cooperative Learning in the Class of Inferential Statistics
}

\author{
Suhaida Abdullah ${ }^{1}$ \\ 1Pusat Pengajian Sains Kuantitatif, Universiti Utara Malaysia, Kedah, Malaysia
}

\begin{tabular}{|c|c|}
\hline (A) Check for updates open 0 access (c) (1) () & DOI : https://doi.org/10.46245/ijorer.v2i6.165 \\
\hline Sections Info & \multirow{12}{*}{$\begin{array}{l}\text { The challenge in teaching statistics encompasses student motivation, } \\
\text { mathematical anxiety, and student understanding. It needs an approach of } \\
\text { education that encourages curiosity and leads to the engagement and } \\
\text { comprehension of students. Cooperative learning is one of the teaching } \\
\text { approaches that can be defined as learning with small groups of friends } \\
\text { and implementing what they have learned in a lecture to achieve the same } \\
\text { objective. Employing cooperative learning in the class of inferential } \\
\text { statistics and assessing the efficacy of this approach is the aim of this study. } \\
\text { The efficiency of the approach is determined based on the student's } \\
\text { perception, the lecture's observation, and the student's performance. The } \\
\text { results showed that students more prefer to learn in a group during the } \\
\text { course. While, based on the lecture's observation, letting students sit in a } \\
\text { group engages students positively during their lessons. After the } \\
\text { implementation of cooperative learning, the student performance also } \\
\text { exhibited improvement. Hence, it is tolerable to conclude that cooperative } \\
\text { learning is efficient in increasing student engagement and performance. }\end{array}$} \\
\hline Article history: & \\
\hline Submitted: October 29, 2021 & \\
\hline Final Revised: November 17, 2021 & \\
\hline Accepted: November 28, 2021 & \\
\hline Published: November 30, 2021 & \\
\hline Keywords: & \\
\hline Cooperative learning & \\
\hline Higher education & \\
\hline Teaching methods & \\
\hline Statistics & \\
\hline 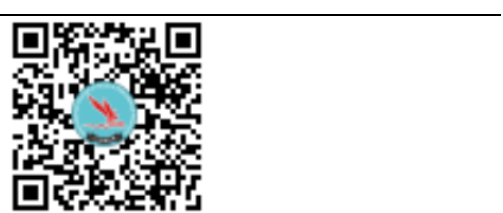 & \\
\hline
\end{tabular}

\section{INTRODUCTION}

In the environment of higher education, teaching is the most important determinant of student learning. The teachers in the higher education institution face various challenges to transform pedagogical practices from teacher-cantered to studentcantered approach (Reeves et al., 2021). Handling a lecture cannot be one-way communication anymore as what the classical teaching method practices. Students can be distracted by numerous attractions during the lecture session. Hence, the lecturer's involvement in fostering the enthusiasm of learning inside the classroom is critical in ensuring that students can acquire knowledge effectively (Davies and Sheldon, 2021).

Mathematics and statistics are vitally used in most fields of study in higher education institutions (Davies \& Sheldon, 2021). For instance, in the school of quantitative sciences, inferential statistics is one of the core programs subjects where all students are compulsory to pass it regardless of their field of the program (either mathematic, statistics, or decision sciences). The knowledge of estimation and statistical hypothesis testing in this course needs to understand the concept of probability to make inferences of a population-based on a sample. Students are generally hard to understand the concept in inferential statistics, which leads to the failure to interpret the result to the real-world application.

The challenges in conducting an inferential statistics course started with the student's perception and motivation (Wilson, 2013). Students commonly feel anxiety when they cannot get to understand what they have learned. It will be directed to the negative perception towards the whole topic in the course and might decrease motivation (Bjälkebring, 2019). According to Nóbrega and da Rocha Falcão (2019), it is 
not very reassuring when a thorough knowledge of generic statistical principles requires more than one semester of instruction. Teaching this foundational level of statistics is challenging since not all students can grasp the concept and apply it to realworld situations afterward. Tadesse et al. (2021); Guo and Sun (2021) indicated that teaching is the most important determinant of student learning in higher education. However, they found out that the higher education teacher is persistent in transforming pedagogical practices from a teacher-centered to a student-centered approach.

To ensure the teaching-learning process can be done effectively, various techniques were introduced. From the passive instructional methods to the active learning approaches, from traditional to technology-savvy approaches, all of these studies aim to increase students' understanding and quality of the teaching and learning process. The cooperative learning approach is one of the active learning approaches (Garfield \& Benzvi, 2008; Adair et al., 2018). In the learning process, cooperative learning encourages collaboration rather than competition. According to Brent et al (2021), Cooperative learning is "organizationally structured group work in which students pursue common goals while being assessed individually." This technique enables the student to learn in a group and achieve the same goal at the end of the lesson. Yaduvanshi and Singh (2015) viewed that cooperative learning is about cooperation among students, where they can share information while discussing content and helping other students. Yaduvanshi and Singh (2015) agreed with this, where they interpreted it as much more than sharing information, discussing content, and helping other students. Throughout this process, the subject matter was concerned with deep insight, and it can be more understandable.

Generally, active learning can be defined as any instructional method that involves the student in the learning activities (Adair et al., 2018; Cho et al., 2021). It means that the student learns by doing activities in the classroom, and the learning process engages the student directly. As time changes, the teaching and learning approaches should also change. Contrary to active learning, traditional lecture emphasizes how the knowledge is delivered, not how the students receive the ability. Nowadays, the young generation is more exposed to open sources of information. In STEM (science, technology, engineering, and mathematics) education, the need to educate students to be creative has drawn increasing attention. Students' creativity can be stimulated via an active learning process, which is recommended for improving education regardless of the discipline (Yang, 2017; Brent et al., 2021). A vital learning principle is that students learn best when they are actively involved in the learning process. Carey and Dunn (2018) showed that in teaching statistics, learning by doing together with group-work dramatically improved student performance. Correspondingly, according to Mujumdar et al. (2021), the problem-based learning (PBL) approach is more effective to increase student understanding, as mentioned previously by (Booth, 2011), wherein general $90 \%$ of students will remember the thing they have learned by doing the real thing.

Henry Ford said that Coming together is a beginning. Keeping together is progress. Working together is a success. Active learning in a classroom can be more effective with cooperative learning (Garfield \& Ben-zvi, 2008). Cooperative learning promotes cooperation rather than competition in the learning process. Cooperative learning appears to benefit students in different ways. As Garfield (1993) discussed, cooperative learning in statistics class particularly encourages comparing other solutions, strategies, and ways to understand the statistical problem given. Using cooperative learning 
provides a broader view, which opens up students' critical thinking to have not only one way to solve most statistical issues. Their communication with peers allows them to express their feelings and realize which topic they have not mastered. By learning in a small group, it appears that students with lower ability improved their performance significantly as students are less intimidated while discussing with peers (Ray et al., 2014).

There are various approaches to cooperative learning in the classroom. Johnson and Johnson (1999) explained the types of cooperative learning described as formal cooperative, informal cooperative, and cooperative based groups. The integration of these types of cooperative learning can be used to create a mood conducive to learning, while Gull and Shehzad (2015) provided a summary of cooperative learning approaches such as Jigsaw, student team achievement division (STAD), and team game tournament (TGT).

It does not take a matter of which cooperative learning approach to be implemented in the classroom as long as the essential elements of cooperative learning are presented. Johnson et al. (2014) identified the crucial elements of cooperative learning: interdependence, face-to-face, individual accountability, social skills, and group processing. Hence, teaching inferential statistics in the classroom through cooperative learning is believed able to develop students' curiosity and engagement. Throughout the activity-based learning, students can participate actively in class while also allowing for plenty of opportunities for experimentation while exploring their knowledge and abilities. This active learning process hopefully might increase the understanding of the subject matter. Hence, this study aims to identify the effectiveness of cooperative learning on student engagement based on the lecturer's observation and the students' perception. At the same time, the performance of the student will indicate the level of students' understanding.

\section{RESEARCH METHOD}

Motivated by the low performance of students on the course of inferential statistics in a few semesters (A142, A171, and A172), this study makes a trial to implement the cooperative learning to a group of students in the following semester, namely A181. All students were considered in the trial since the only group took the course in the particular semester. Hence, there was no hypothesis testing required. The implementation of group work activities in the classroom can be described as the following:

1. Target classroom

Only one group of students took this course in semester A181 handled by a particular lecturer. So, this group is automatically considered as the experimental unit. However, a comparison study was also done on the student's performance between semester A181 and the previous semester, namely A142, A171, and A172, which the same lecturer also conducted.

2. Student's group selection process

In the second week of the lecture, students were required to form a group of two to four. The self-selection of the group was adopted to minimize the awkward feeling among students during the activities and maximize their relaxation, hence facilitating them to express their understanding for knowledge sharing. 
3. Activities: tasks and materials

The problems were given to all groups according to the topics discussed. Students had to discuss solutions to the given problems and learned the issues with the guidance of the lecturer. Students were also provided with lecture notes and online references. During the activities, students were encouraged to ask questions to the lecturer.

4. Evaluating students' learning

At the end of the activities, students shared their group findings with the entire class. All students allowed themselves to express their opinions and suggestions. Immediate evaluation and correction on the lecturer's group work findings help students identify their mistakes, and at the same time, the other groups also learn from the mistakes. The individual evaluation was based on the student's performance in the coursework and final examination.

5. Identifying lecturer's observations and student's reflection

To assess the effectiveness of cooperative learning through the group activities in the classroom, the lecturer's observations on the student's behavior during the activities were considered. Besides that, questionnaires were distributed to the students to determine their perceptions about the activities and get feedback on their experiences. Information about student interest level towards the subject is also collected as listed in Table 1.

The eight items were taken from the Survey on Attitude Toward Statistics SATS36 (Schau et al.,1995), as adopted by other researchers such as Zain et al (2017). The interval scale from one to seven was used to represent strongly disagree to agree, respectively strongly.

Table 1. The questionnaire items related to students' interest in statistics.

\begin{tabular}{cl}
\hline $\begin{array}{c}\text { Number } \\
\text { of items }\end{array}$ & \multicolumn{1}{c}{ Questionnaire } \\
\hline 1 & I will like statistics. \\
2 & Statistics should be a required part of my professional training \\
3 & I am interested in being able to communicate statistical information to others. \\
4 & I will enjoy taking statistics courses. \\
5 & I am interested in using statistics. \\
6 & I am interested in understanding statistical information. \\
7 & I am interested in learning statistics. \\
8 & I can learn statistics. \\
\hline
\end{tabular}

\section{RESULTS AND DISCUSSION}

The effectiveness of cooperative learning evaluated based on the lecturers' observations, students' perceptions, and interest in the subject, are discussed in sequence.

\section{The observations by the lecturer}

During the group activities, the lecturer observed students' behavior of both positive and negative effects. The positive impact of cooperative learning on the students' behavior during the lecture is that students showed their commitment to participate in the in-group discussions. George and Supreetha (2021) mentioned that group activities can motivate students and keep them engaged for the entire session. Students also seemed more comfortable asking questions, but they still preferred to ask it personally 
when the lecturer came to their group rather than raising their hands and asking loudly. This observation was also found by Gillies (2020), where students became more adept at expressing their opinions and providing explanations and justifications.

From this observation, the lecturer was also able to figure out the students' weaknesses in the course. The discussions after the activities also gave them courage and confidence to share their understanding or opinions. However, some adverse effects were observed from the activities, such as more time needed to finish a particular topic, while the course is restricted with the scheme of work.

\section{The perceptions of the students}

At the end of the semester, the students completed a questionnaire regarding their opinions about group activities. Based on Figure 1, most students (88\%) chose group activities during the course. Most of the students preferred to have the activities during lectures instead of a traditional lecture. They felt easier to understand particular topics and more comfortable communicating with their friends and lecturer. From the group activities, students also felt motivated to commit to the class since their opinions or questions were not considered as coming from the individual student, but on behalf of the group instead. Some students also felt that working in a group lessens their burden to solve a given problem. It was also a platform to share more and different ideas.

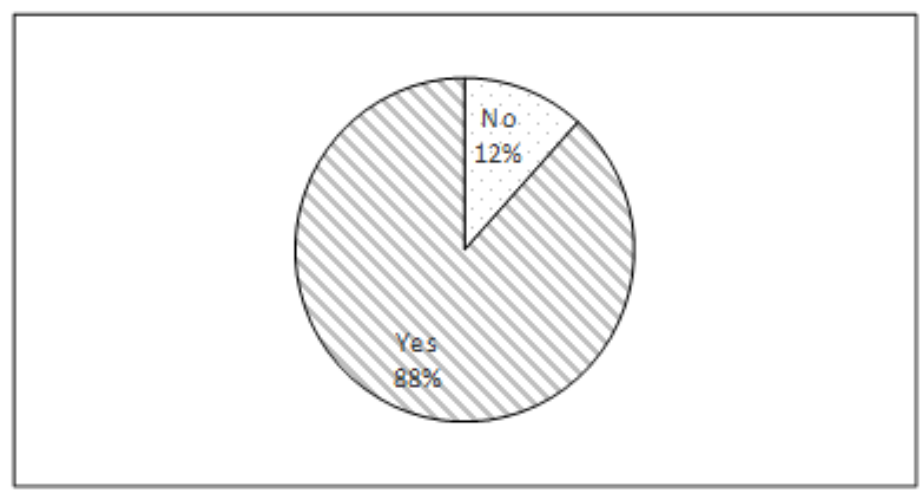

Figure 1. The percentages of students prefer to have group activities during the lecture.

Other research found similar outcomes, with students preferring active teaching and learning processes in class. According to Kanchana et al. (2019); Gillies (2020), students felt comfortable sharing their learning process in a group setting (2020).

\section{Student's interest level toward the subject}

Many students did not show much interest in mathematics or statistics courses, which led them to negatively feel towards the classes Sockol et al. (2021). The teaching and learning approach might influence the interest of the students in the course. As concluded in Shamsuddin et al. (2018), the educators or lecturers should give more attention to students' interest in mathematics to be more receptive to learning mathematics.

Survey of Attitudes Toward Statistics (SATS-36) is an instrument first developed by Schau et al. (1995). The device was tested and validated a few times. The latest was done by $\mathrm{Xu}$ and Schau (2021), which provided the empirical support for the use of the SATS-36 in studying contextual variables about statistics instructors. Many studies also 
used this instrument to identify how students' attitudes towards statistics, such as Zain et al. (2017); Sarikaya et al. (2018); Persson et al. (2019).

To measure students' perception about the inferential statistics course in semester A181, this study used eight variables in SATS-36 as stated in Table 1 to measure students' interest level. The responses on students' interest level towards statistics based on the eight questions are summarized in Figure 2. The higher the value represents the higher agreement on the question. Most of the students have a level of agreement of more than 4 (where the first quartile of all boxplots is above 4 ). This indicates that most of them have a high interest in the subject.

Based on some works of the literature indicated that the implementation of cooperative learning increase students' interest in the course (Sockol et al., 2021; Williams et al., 2017), this study believes the positive perception of the students were affected by the approach of cooperative learning in the class. However, further investigation in the future should be done to support this statement.

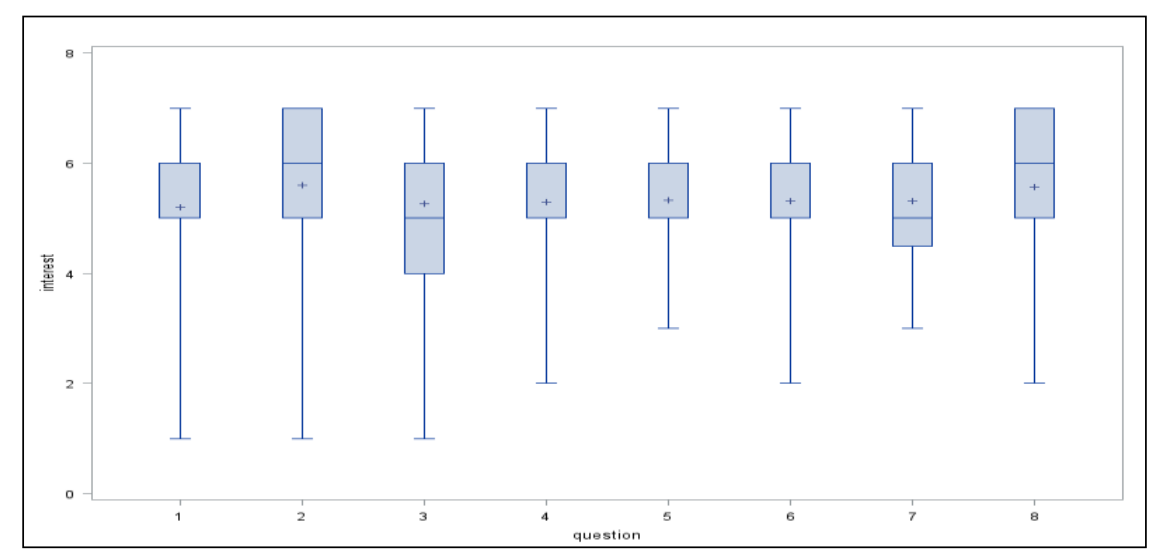

Figure 2. Boxplots of eight items regarding students' interest level towards statistics.

\section{Student's performance}

Before implementing the cooperative learning approach in the class of inferential statistics, the students' performance for the previous semester (before semester A181) can be said not good. Figure 3 shows the performance of the student based on the final examination score. The first boxplot delivers the performance of students in semester A181 who went through the cooperative learning approach. While for the other three boxplots were the performance of students for the semester before A181, which did not go through the cooperative learning. To be noticed, these groups of students were conducted by the same lecturer.

Based on the final examination score, it was apparent that the score for semester A181 was higher than the other semesters. The median score of the students in semesters A142, A171, and A172 obtained was below 50\% (refer to the middle line of the boxplot). The result for semester A181 increases with a median score of almost $60 \%$. The average score of the final examination (the ' $X$ ' sign in Figure 3) also increased as in the previous semester; the averages were $37.01 \%, 36.12 \%$, and $41.91 \%$ for semesters A172, A171, and A142, respectively. But in semester A181, the average score is 56.65\%. This finding shows the effectiveness of the cooperative learning approach to increase the performance of the students. Study by Palazón-Herrera (2021) and Buchs et al (2021) also provide the same conclusion. 


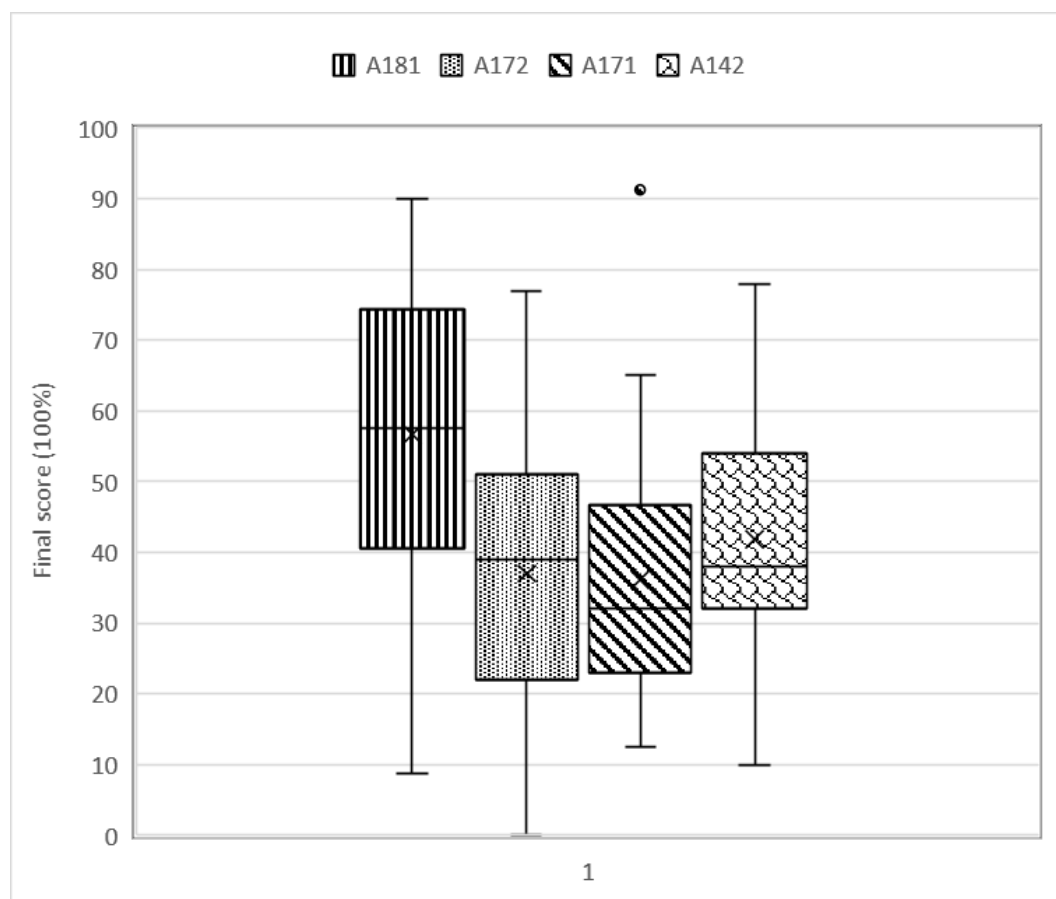

Figure 3. Students' performance is based on the final examination result.

\section{CONCLUSIONS}

Student engagement in the classroom is an essential indicator of knowledge transfer. Active learning through the cooperative learning approach provides a better option of handling a lecture for the inferential statistics students. The results show that learning in a small group promotes students to self-learn and knowledge-sharing in the class with the guidance of the lecturer, well-planned activities, and sufficient references. The implication is the lecturer in terms of assessing students' understanding and correcting any mistakes immediately during learning, instead of waiting until the graded assessment time. In addition, cooperative learning also helps the students to understand more about the subject matters. This was indicated by comparing the final examination result between semesters with cooperative learning and without it. Future research can improve the quality of cooperative learning at a different level.

\section{ACKNOWLEDGEMENTS}

The authors would like to acknowledge Universiti Utara Malaysia for funding this study via the SoTL research grant with S/O code:14154.

\section{REFERENCES}

Adair, D., Jaeger, M., \& Price, O. M. (2018). Promoting active learning when teaching introductory statistics and probability using a portfolio curriculum approach. International Journal of Higher Education, 7(2), 175-188. https:/ / doi.org/10.5430/ijhe.v7n2p175

Bjälkebring, P. (2019). Math anxiety at the university: What forms of teaching and learning statistics in higher education can help students with math anxiety?. Frontiers in Education, 4(30), 1-11. https://doi.org/10.3389/feduc.2019.00030

Booth, C. (2011). Reflective teaching, effective learning: Instructional literacy for library educators. Chicago: American Library Association. 
Brent, R., Prince, M., \& Felder, R. (2021). Promoting and managing student-student interactions in online STEM classes. International Journal of Engineering Education, 37(3), 797-813.

Buchs, C., Dumesnil, A., Chanal, J., \& Butera, F. (2021). Dual effects of partner's competence: resource interdependence in cooperative learning at elementary school. Education Sciences, 11(5), 210-215.

Carey, M. D., \& Dunn, P. K. (2018). Facilitating language-focused cooperative learning in introductory statistics classrooms: A case study. Statistics Education Research Journal, 17(2), 30-50. https:// doi.org/10.52041/serj.v17i2.157

Cho, H. J., Zhao, K., Lee, C. R., Runshe, D., \& Krousgrill, C. (2021). Active learning through flipped classroom in mechanical engineering: Improving students' perception of learning and performance. International Journal of STEM Education, 8(1), 1-13. https://doi.org/10.1186/s40594-021-00302-2

Davies, N., \& Sheldon, N. (2021). Teaching statistics and data science in England's schools. Teaching Statistics, 43(1), 52-70.

Garfield, J. (1993). Teaching statistics using small-group cooperative learning, journal of statistics education, 1(1), 1-10. https:/ / doi.org/10.1080/10691898.1993.11910455

Garfield, J., \& Ben-Zvi, D. (2008). Developing students' statistical reasoning: Connecting research and teaching practice. USA: Springer.

George, S. V. \& Supreetha, R. (2021). A reward-based active learning approach for motivating and engaging students in a large classroom. Journal of Engineering Education $\begin{array}{lll}\text { Transformations, } & \text { 34(Special Issue), }\end{array}$ https:/ / doi.org/10.16920/jeet/2021/v34i0/157215

Gillies, R. M. (2020). Dialogic teaching during cooperative inquiry-based science: A case study of a year 6 classroom. Education Sciences, 10(11), 1-20.

Gull, F., \& Shehzad, S. (2015). Effects of cooperative learning on students' academic achievement. Journal of Education and Learning, 9(3), 246-255.

Guo, Y., \& Sun, Q. (2021). Research and practice on the reform of postgraduate teaching mode guided by cultivating compound and applied talents-taking mathematical statistics for example. Journal of Physics: Conference Series, 1903(1), 1-8.

Johnson, D. W., \& Johnson, R. T. (1999). Making cooperative learning work. Theory Into Practice, 38(2), 67-73.

Johnson, D. W., Johnson, R. T., \& Smith, K. A. (2014). Cooperative learning: Improving university instruction by basing practice on validated theory. Journal on Excellence in College Teaching, 25(3), 85-118.

Kanchana, S., Patchainayagi, S. \& Rajkumar, S. (2019). Empowering students to become effective learners through activity-based learning. Humanities and Social Sciences Reviews, 7(5), 57-62.

Mujumdar, S. B., Acharya, H., \& Shirwaikar, S. (2021). Measuring the effectiveness of PBL through shape parameters and classification. Journal of Applied Research in Higher Education, 13(1), 342-368. https://doi.org/10.1108/JARHE-08-2018-0175.

Nóbrega, G. M. M., \& da Rocha Falcão, J.T. (2019). Approaching challenges in teaching learning process of statistics in psychology graduation courses: A didatic contract overlook. Bolema - Mathematics Education Bulletin, 33(65), 1155-1174.

Palazón-Herrera, J. (2021). Secondary school music education students' perception of technology-assisted cooperative learning (Percepción del alumnado de música de educación secundaria sobre el aprendizaje cooperativo asistido por tecnología). Cultura y Educacion, 33(1), 160-188.

Ray, P. S., Leeper, J., \& Amini, M. O. (2014). Effects of cooperative learning as a teaching method for an introductory course in engineering statistics. ASEE Southeast Section Conference, 2014(1), 1-9. 
Persson, I., Kraus, K., Hansson, L., Wallentin, F.Y. (2019). Confirming the structure of the survey of attitudes toward statistics (Sats-36) by Swedish students. Statistics Education Research Journal, 18(1), 83-93.

Reeves, K. A., Hernandez-Gantes, V., Centeno, G., \& Nurnberg, C. G. (2021). Constructivist exercises to enhance teaching of probability and statistics for engineers. Informs Transactions on Education, 22(1), 55-64. https://doi.org/10.1287/ited.2021.0246

Sarikaya, Emmioglu, E., Ok, A., Aydin, Y. P., \& Schau, C. (2018). Turkish version of the survey of attitudes toward statistics: Factorial structure invariance by gender. International Journal of Higher Education, 7(2), 121-127.

Schau, C., Stevens, J., Dauphinee, T. L., \& Del Vecchio, A. (1995). The development and validation of the survey of attitudes toward statistics. Educational and Psychological Measurement, 55(1), 868-875.

Shamsuddin, M., Mahlan, S. B., Ul-Saufie, A. Z., Hussin, F., Alias, F. A. (2018). An identification of factors influencing student's attitude and perception towards mathematics using factor analysis. AIP Conference Proceedings, 1974(1), 1-10. https://doi.org/10.1063/1.5041706

Sockol, L. E., Ellison, W. D., Stutts, L. A., \& Knouse, L. E. (2021). Improving quantitative abilities and attitudes in clinical psychology courses: Longitudinal assessment of a blended $\begin{array}{llll}\text { learning intervention. Teaching of Psychology, 48(4), 316-327. } & \text {, }\end{array}$ https://doi.org/10.1177/0098628320979894

Tadesse, T., Asmare, A., Ware, H. (2021). Exploring teachers' lived experiences of cooperative learning in Ethiopian higher education classrooms: A phenomenological-case study. Education Sciences, 11(7), 332-340. https://doi.org/10.3390/educsci11070332

Williams, J. L., McCutcheon, L. E., Fava, D. A., \& Aruguete, M. S. (2017). Using research on celebrity admiration to enhance your statistics class. North American Journal of Psychology, 19(3), 585-599.

Wilson, S. G. (2013). The flipped class: A method to address the challenges of an undergraduate $\begin{array}{lllll}\text { statistics } \quad \text { course. Teaching of Psychology, 40(3), 193-199. } & \text { of }\end{array}$ https://doi.org/10.1177/0098628313487461

Xu, C., \& Schau, C. (2021). Measuring statistics attitudes at the student and instructor levels: a multilevel construct validity study of the survey of attitudes toward statistics. Journal of Psychoeducational Assessment, 39(3), 315-331.

Yaduvanshi, S., \& Singh, S. (2015). Cooperative learning: An innovative pedagogy for achieving educational excellence. International Journal of Applied Research 2015, 1(11), 174-279.

Yang, D. (2017). Instructional strategies and course design for teaching statistics online: Perspectives from online students. International Journal of STEM Education, 4(1), 34-45. https:// doi.org/10.1186/s40594-017-0096-x

Zain, Z., Abdullah, S., Khalid, K., \& Murat, I. Z. (2017). Evaluating the effectiveness of new approach in teaching elementary statistics. Man In India, 97(24), 313-322.

\footnotetext{
${ }^{*}$ Dr. Suhaida Abdullah (Corresponding Author)

Pusat Pengajian Sains Kuantitatif,

Universiti Utara Malaysia

06010 Sintok, Kedah, Malaysia

Email: suhaida@uum.edu.my
} 